\title{
PENGUATAN KARAKTER TOLERAN DALAM PEMBELAJARAN BAHASA INDONESIA BERBASIS WHOLE LANGUAGE DI MADRASAH IBTIDAIYAH
}

\author{
Hamidulloh Ibda \\ h.ibdaganteng@stainutmg.ac.id
}

\begin{abstract}
Abstrak
Artikel ini membahas dinamika intoleransi dari aspek pikiran, bahasa, tindakan dan solusinya melalui penguatan pendidikan karakter toleran dalam pembelajaran Bahasa Indonesia. Intoleransi dalam praktiknya bisa berupa kata-kata kasar, ujaran kebencian, pelecehan, hingga aksi radikalisme. Penguatan pendidikan karakter adalah amanat yang harus dilaksanakan dalam Madrasah Ibtidaiyah. Ada tujuh belas karakter wajib yang diimplementasikan. Mulai karakter religius, jujur, toleran, disiplin, bekerja keras, kreatif mandiri, demokratis, rasa ingin tahu, semangat kebangsaan, cinta tanah air, menghargai prestasi, komunikatif, cinta damai, suka membaca, lingkungan dan peduli, kepedulian sosial, dan bertanggung jawab. Toleransi menjadi salah satu karakter mendesak yang diperkuat di era revolusi industri keempat ini. Bahasa anak-anak mewakili karakternya. Semakin sopan, halus, dan toleran terhadap bahasa mereka, semakin kuat karakter sopan, halus, dan toleran terhadap mereka, dan sebaliknya. Pembelajaran bahasa Indonesia dengan pendekatan bahasa utuh dapat memperkuat karakter toleran karena dilakukan utuh, integral, tidak parsial dari aspek mendengarkan, membaca, menulis dan berbicara. Pemahaman bahasa dalam pendekatan ini tidak hanya tekstual, tetapi kontekstual dan bahkan intertekstual. Pembelajaran bahasa Indonesia melalui pendekatan whole language bertujuan untuk memperkuat karakter toleran, santun, peduli sosial dan bermuara pada sikap toleransi beragama. Ada dua indikator toleransi agama, kepada orang-orang sesama agama, dan toleransi terhadap orang-orang dari berbeda agama.
\end{abstract}

Kata Kunci: Karakter Toleran, Bahasa Indonesia, Madrasah Ibtidaiyah, Whole Languange

\begin{abstract}
This article discusses the dynamics of intolerance from aspects of mind, language, action and solution through strengthening the education of tolerant character in learning Indonesian. Intolerance in practice can be harsh words, hate speech, harassment,
\end{abstract}


until the action of radicalism. Strengthening character education is a mandate that must be implemented in Islamic elementary education. There are seventeen required implemented characters. Start religious character, honest, tolerant, disciplined, hard working, creative independent, democratic, curiosity, spirit of nationality, love of the homeland, appreciate achievement, communicative, love peace, love reading, caring environment, social care, and responsible. Tolerance became one of the urgent characters strengthened in this era of the fourth industrial revolution. The language of the children represents its character. The more polite, refined, and tolerant of their language, the stronger the character is polite, refined, and tolerant to them, and vice versa. Indonesian language learning with whole language approach can strengthen the tolerant character because it is done intact, integral, not partial from aspects of listening, reading, writing and speaking. The language understanding in this approach is not just textual, but contextual and even intertextual. Indonesian language learning through whole language approach aims to strengthen the character of tolerant, polite, social care and boils down to the attitude of religious tolerance. There are two indicators of religious tolerance, to people of fellow religion, and tolerance to people of different religions.

Keywords: Tolerant Character, Indonesian, Islamic Elementary Education, Whole Languange

\section{A. Pendahuluan}

Tantangan pendidikan dasar Islam saat ini tidak hanya kompetensi dan literasi, namun juga karakter. Munculnya gerakan radikalisme, intoleransi, ujaran kebencian, perundungan di ruang publik menjadi tesis pendidikan karakter toleran urgen dikuatkan.

Terorisme dan radikalisme tumbuh dari doktrin keliru. Radikalisme merupakan faham atau aliran yang menginginkan perubahan sosial-politik secara cepat dengan cara-cara kekerasan. Dimensi radikalisme ada dua. Pertama kekerasan yang menekankan kekerasan sebagai alat mengubah sistem yang sudah mapan. Kedua, usaha aktif melakukan perubahan masyarakat secara radikal. ${ }^{1}$ Dimensi keduanya identik dengan gerakan pemikiran, kata-kata, sampai tindakan merusak.

Intoleransi mulai tumbuh di lingkungan pendidikan. Riset Kemendikbud menemukan, dari 160 responden (siswa, guru, kepala sekolah, akademisi) pada rentang Juli-September 2016, mendapatkan opini pemimpin harus seagama. SETARA Institute menemukan 11 persen siswa menilai khilafah sebagai sistem pemerintahan paling baik. Mereka menganggap kekerasan sebagai solusi memecahkan masalah dengan menggunakan ayat-ayat untuk merekrut anggota baru. ${ }^{2}$ Pemaksaan menjadi ciri khas gerakan mereka dengan doktrin mengaku paling benar.

1 Ali Muhtarom, dkk, Islam Agama Cinta Damai (Upaya Menepis Radikalisme Beragama), (Semarang: CV. Pilar Nusantara, 2018), hlm. 18.

2 Muhammad Nur Rochmi, "Intoleransi Mulai Tumbuh dalam Pendidikan”, Berita, 3 Mei 2017, beritagar.id/ artikel/berita/intoleransi-mulai-tumbuh-dalam-pendidikan diakses pada 18 Juli 2018. 
Mereka sepakat menolak pemimpin di luar agama mereka sehingga memicu tumbuhnya intoleransi. Faham seperti ini harus diputus mata rantainya melalui kegiatan pembelajaran di sekolah. Penguatan karakter terutama toleransi harus berpusat pada pembelajaran yang dilakukan guru.

Survei Pusat Pengkajian Islam dan Masyarakat UIN Syarif Hidayatullah Jakarta menunjukkan pengaruh intoleransi dan radikalisme menjalar ke sekolah dan universitas. Ada 51,1 persen responden mahasiswa/siswa beragama Islam memiliki opini intoleran terhadap aliran Islam minoritas seperti Ahmadiyah dan Syiah. Terdapat 34,3 persen responden sama, tercatat memiliki opini intoleransi kepada agama selain Islam.

Sebanyak 48,95 persen responden siswa/mahasiswa merasa pendidikan agama mempengaruhi mereka untuk tidak bergaul dengan pemeluk agama lain. Dari 58,5 persen responden memiliki pandangan keagamaan pada opini radikal. ${ }^{3}$ Penelitian Wahid Foundation dan LSI (2016) dengan sebaran 1.520 siswa di 34 provinsi menyebut 7,7 \% siswa SMA siap melakukan tindakan radikal untuk tujuan tertentu. Salah satunya pemurnian Islam. ${ }^{4}$

Pemaknaan jihad yang keliru memicu munculnya intoleransi. Dalam sejarahnya, proses Islamisasi yang dulu damai berubah ketika Indonesia memasuki Reformasi 1998. Tim Pusham UII, mencatat akhir masa Orde Baru menjadi momentum kebangkitan Islam di Indonesia, yang menjadi prakondisi munculnya kelompok gerakan Islam baru termasuk gerakan Islam radikal.

Dalam atmosfer kebebasan ini bermunculan aktor gerakan Islam baru, yang berada di luar kerangka mainstream Islam di Indonesia yang dominan, seperti NU, Muhammadiyah, Persis, Al-Irsyad, Al-Wasliyah, Jamiat Khair dan sebagainya. Organisasi-organisasi sekaliber Gerakan Tarbiyah (embrio Partai Keadilan Sejahtera), Hizbut Tahrir Indonesia (HTI), Majelis Mujahidin Indonesia (MMI), Front Pembela Islam (FPI), Laskar Jihad dan sebagainya merupakan representasi generasi baru gerakan Islam di Indonesia yang cenderung radikal. ${ }^{5}$

Sebelum HTI dibubarkan pemerintah, ada beberapa ormas perlu diwaspadai karena diduga mengajarkan intoleransi. Mulai Aliansi Nasional Anti Syiah (ANNAS), Jamaah Ansarut Tauhid (JAT), Majelis Mujahidin Indonesia (MMI), Forum Umat Islam (FUI), dan Front Pembela Islam (FPI).

Ormas-ormas di atas bertentangan dengan prinsip Pancasila sebagai dasar negara Indonesia. Ormas di atas sama sekali tidak menjunjung tinggi perdamaian dan toleransi. Sebaliknya, mereka menjunjung tinggi provokasi demi perpecahan dan seolah-olah ingin memindahkan konflik di Timur Tengah ke Indonesia. ${ }^{6}$

3 Terry Muthahhari, "Survei UIN Jakarta: Intoleransi Tumbuh di Banyak Sekolah dan Kampus”, Sosial Budaya, 8 November 2017, tirto.id/survei-uin-jakarta-intoleransi-tumbuh-di-banyak-sekolah-dan-kampus-czQL diakses pada 18 Juli 2018.

4 Ubaid Matraji, "Mewaspadai Wabah Intoleransi di Sekolah”, Kolom, 5 Juli 2017, news.detik.com/ kolom/d-3520475/mewaspadai-wabah-intoleransi-di-sekolah Diakses pada 18 Juli 2018.

5 Toto Suharto, "Gagasan Pendidikan Muhamamdiyah dan NU sebagai Potret Pendidikan Islam Moderat di Indonesia," Jurnal Islamica, Volume 9, Nomor 1, September 2014, hlm. 82.

6 Tsamara Amany, "Ini Dia 6 Ormas Yang Harus Dibubarkan Pemerintah," Artikel, 17 Januari 2016, redaksiindonesia.com/read/ini-dia-6-ormas-yang-harus-dibubarkan-pemerintah.html diakses pada 19 Juli 2018. 
Ada sejumlah ormas pengusung radikalisme dan cenderung intoleran, baik dari aspek fikrah (pemikiran) sampai harakah (gerakan). Mulai dari kelompok Salafi-Wahabi, Negara Islam Irak dan Syam/Islamic State Of Iraq And Al-Sham (ISIS), Jamaah Ansharut Tauhid (JAT), Jemaah Islamiyah, Hizbut Tahrir, Ikhwanul Muslimin, Al Qaeda dan lainnya. ${ }^{7}$

Badan Nasional Penanggulangan Teroris (BNPT) menyebut tujuh kampus terpapar radikalisme. Mulai Universitas Indonesia (UI), Institut Teknologi Bandung (ITB), Institut Pertanian Bogor (IPB), Universitas Diponegoro (Undip), Institut Teknologi Sepuluh Nopember (ITS), Universitas Airlangga (Unair), dan Universitas Brawijaya (UB).

Kemenristek Dikti menjelaskan paparan radikalisme di kampus berlangsung sejak 35 tahun silam pada 1983. Kala itu pemerintah menerapkan Normalisasi Kehidupan Kampus/ Badan Koordinasi Kemahasiswaan (NKK/BKK). Sehingga praktis kehidupan politik di kampus dilarang. Kekosongan itu diisi kelompok penyebar faham radikal. ${ }^{8}$

Kekerasan di dunia maya berbentuk hate speech (ujaran kebencian), bullying (perundungan), dan persekusi juga marak. Southeast Asia Freedom of Expression Network merillis data, persekusi sejak Januari 2017 meningkat pada Mei 2017. Pada Januari ada 7 korban, Februari 3 korban, Maret 2 korban, April 13 korban, puncaknya terjadi pada Mei sebanyak 63 kasus. ${ }^{9}$

Kasus bullying di sekolah di Indonesia peringkat teratas dalam catatan Komisi Perlindungan Anak Indonesia (KPAI) dari sektor pendidikan. KPAI mencatat 369 pengaduan terkait bullying dari Januari 2011-Agustus 2014. Jumlah itu sekitar 25\% dari total pengaduan di bidang pendidikan ada 1.480 kasus. ${ }^{10}$ Kemensos pada 2017 mencatat 84 persen anak usia 12-17 tahun pernah terkena bullying. Sejak Januari hingga 15 Juli 2017, tercatat ada 976 pengaduaan dan 17 adalah bullying. ${ }^{11}$

Dalam dunia bahasa, faktor sosial di atas menjadi pemicu rendahnya kualitas bahasa anak. Salah satu faktor dominan adalah perubahan situasi yang makin kompleks, buruk, dan penuh kekerasan. Sementara pembinaan berbahasa berkualitas dan santun kurang diperhatikan, bahkan tidak diajarkan di lembaga pendidikan. Faktor ini menjadikan anak-anak bertutur kata buruk. ${ }^{12}$

Lembaga pendidikan harus menjamin karakter anak. Meski pemeluk Islam di Indonesia mayoritas, namun tidak boleh memaksa kehendak. Faham toleransi harus diutamakan agar spirit beragama dan bernegara sejalan. Sejak pra kemerdekaan, di Indonesia sudah muncul berbagai

7 Ali Muhtarom, dkk, Islam Agama Cinta Damai (Upaya Menepis Radikalisme Beragama),... hlm.28.

8 Eko Prasetya, "7 Kampus Negeri Ternama Terpapar Radikalisme, UI dan Undip Termasuk", Berita, 31 Mei 2018, www.merdeka.com/peristiwa/7-kampus-negeri-ternama-terpapar-radikalisme-ui-dan-undip-termasuk.html diakses pada 19 Juli 2018.

9 Mohammad Teja, "Media Sosial: Ujaran Kebencian Dan Persekusi”, Majalah Info Singkat, Vol. IX, No. 11/I/ Puslit/Juni/2017, Hlm.11.

10 Firmansyah, "Jumlah Kejadian Bullying dari Tahun ke Tahun," etd.repository.ugm.ac.id diakses pada 20 Juli 2018, hlm.2

11 Tim Viva, "Kasus Bullying Anak Meningkat pada 2017", https://www.viva.co.id/berita/nasional/938446kasus-bullying-anak-meningkat-pada-2017, 23 Juli 2017, diakses pada 20 Juli 2018.

12 EA Aziz, "Gaya Ki Sunda Menyatakan 'Tidak': Sebuah Telaah Sosiolinguistik Terhadap Variabel Sosial yang Mempengaruhi Realisasi Kesantunan dalam Pertuturan Menolak oleh Orang Sunda," Makalah Konferensi Internasional Budaya Sunda 1, UPI Bandung, 2001, hlm.1 
faham pemurnian Islam yang membenturkan spirit beragama dan bernegara. Padahal agama, negara, nasionalisme bisa berjalan senada dan seirama tanpa perlu dipertentangkan.

Penguatan ideologi melalui pendidikan karakter sangat penting. Dalam pendidikan, ideologi merupakan sumber kekuasaan dalam mengarahkan pendidikan. ${ }^{13}$ Masa depan anak, kesuksesan maupun kegagalan banyak dipengaruhi pendidikan termasuk peran orang tua di masa kecil anak. Komunikasi yang dibina maksimal akan memberikan dasar terpenting dalam pendidikan anak. ${ }^{14}$

Thomas Lickona (1992) menyebut ada 10 tanda kehancuran suatu bangsa. Pertama, meningkatnya kekerasan pelajar. Kedua, penggunaan bahasa dan kata-kata buruk. Ketiga, pengaruh peer group dalam kekerasan. Keempat, meningkatnya perilaku merusak diri (penggunaan narkoba dan seks bebas). Kelima, makin kaburnya pedoman baik dan buruk. Keenam, menurunnya etos kerja. Ketujuh, rendahnya rasa hormat kepada orang tua dan guru. Kedelapan, rendahnya tanggungjawab individu dan warga negara. Kesembilan, membudayanya ketidakjujuran. Kesepuluh, adanya rasa saling curiga dan kebencian di antara sesama. ${ }^{15}$

Bahasa Indonesia sebagai jati diri dan kekayaan bangsa harus dikuatkan dalam pembentukan karakter anak. Karakter asli manusia Indonesia sangat luhur dan berbeda dengan pendapat Thomas Lickona di atas. MC Cain dan Mark Salter (2009) menyebut karakter asli manusia Indonesia identik dengan kejujuran, rasa hormat, autentisitas, kesetiaan, kerja sama, berbudi luhur, tanggung jawab, kendali diri, kepercayaan, kepatuhan, kelenturan, kerja keras, optimis, iman, cinta kasih, toleransi, unggul dan ikhlas. ${ }^{16}$

Bahasa yang diterima anak menentukan karakternya. Penguasaan bahasa anak sangat dipengaruhi keluarga, lingkungan dan teknologi. Dalam psikolinguistik, ada tiga hal mendasar dalam bahasa yaitu pemahaman bahasa, pemerolehan bahasa dan produksi bahasa. ${ }^{17}$

Sebagai alat komunikasi, bahasa menentukan pembentukan pendapat dan sikap bahkan menentukan pendapat umum (public opinion). ${ }^{18}$ Jika pemerolehan dan produksi dan bahasa pada anak baik, mereka baik dalam pikiran dan perbuatannya. Jika sebaliknya, mereka rentan berperilaku intoleran.

Dari penjelasan dan data di atas, dapat disimpulkan ke dalam beberapa simpulan. Pertama, intoleransi merupakan tindakan yang harus dijauhkan dari pendidikan dan merugikan negara dan agama. Kedua, munculnya faham radikal, intoleran, ujaran kebencian, dan perundungan,

13 H.A.R Tilaar, Pendidikan dan Kekuasaan: Suatu Tinjauan dari Perspektif Studi Kultural, (Magelang: Indonesia Tera, 2003), 120.

14 Lianny Solihin, "Tindakan Kekerasan pada Anak dalam Keluarga", Jurnal Pendidikan Penabur, No.03 / Th.III / Desember 2004, hlm. 139.

15 Dwi Astuti Martianto, Pendidikan Karakter: Paradigma Baru dalam Pembentukan Manusia, (Yogyakarta: BPFE, 2002), hlm.2-3.

16 Hamidulloh Ibda dan Dian Marta Wijayanti, Siapkah Saya Menjadi Guru SD Revolusioner? (Depok: Kalam Nusantara, 2014), hlm.56-57.

17 I Nengah Sudipa, "Psycholinguistics : An Introductory Note," Essay Majalah, volume 16. English Department 2009, Udayana University, hlm.1

18 Onong Uchjana Effendy, Ilmu, Teori \& Filsafat Komunikasi, (Bandung : PT. Citra Aditya Bakti, 1993), hlm. 27 . 
muncul dalam pendidikan karena belum maksimalnya pendidikan karakter. Apalagi, kelompok radikal tidak pernah surut dalam mengampanyekan faham dan ideologi yang mereka yakini. Mereka menyusup ke lembaga pendidikan melalui berbagai cara.

Ketiga, gempuran faham intoleransi memiliki klasifikasi berbeda. Ada yang pada tataran fikrah (pemikiran, doktrin), aqidah (keyakinan), amaliyah (tradisi), harakah (gerakan). Kerusakan ini dalam berbagai lini kehidupan sangat ditentukan dari pendidikan dan pembelajaran Bahasa Indonesia. Bahasa menjadi peranti utama masuknya pengetahuan, informasi dan karakter. Jika yang diterima baik, santun, toleran, anak-anak cenderung santun dan toleran. Maka dibutuhkan pendekatan pembelajaran Bahasa Indonesia yang mampu membentuk karakter toleran.

\section{B. Pembahasan}

\section{Penguatan Pendidikan Karakter di Madrasah Ibtidaiyah}

Madrasah Ibtidaiyah sebagai salah satu jenjang pendidikan dasar Islam formal harus mengikuti regulasi pemerintah dalam menyukseskan pendidikan karakter. Thomas Lickona mengemukakan pendidikan karakter merupakan pendidikan untuk membentuk kepribadian melalui pendidikan budi pekerti yang hasilnya terlihat dalam tindakan nyata seorang, yaitu tingkah laku baik, jujur, bertanggung jawab, menghormati hak orang lain, dan kerja keras. ${ }^{19}$

Pendidikan karakter menjadi isu strategis dewasa ini. Hal itu bisa kita lihat dari banyaknya kasus dekadensi moral yang sudah masuk dalam dunia pendidikan. Mulai dari penganiayaan yang dilakukan siswa bahkan sampai pembunuhan. ${ }^{20}$

Kemendikbud mengeluarkan Permendikbud Nomor 23 tahun 2015 tentang Penumbuhan Budi Pekerti (PBP). Dalam pelaksanaan PBP, ada beberapa nilai dasar kebangsaan dan kemanusiaan. Pertama, internalisasi sikap moral dan spiritual, yaitu menghayati hubungan spiritual dengan Sang Pencipta yang diwujudkan sikap moral menghormati sesama makhluk hidup dan alam sekitar.

Kedua, keteguhan menjaga semangat kebangsaan, kebhinekaan, untuk merekatkan persatuan bangsa, yaitu mampu terbuka terhadap perbedaan bahasa, suku bangsa, agama, dan golongan, dipersatuan keterhubungan mewujudkan tindakan bersama sebagai satu bangsa, Tanah Air, berbahasa sama yaitu Bahasa Indonesia. ${ }^{21}$

Pemerintah melalui Kemendikbud melakukan banyak revisi tentang pendidikan karakter. Di dalamnya ada beberapa karakter yang hampir sama dengan 18 karakter sesuai Undangundang Nomor 20 tahun 2003 tentang Sistem Pendidikan Nasional (Sisdiknas). Pada program Penguatan Pendidikan Karakter (PPK) tahun 2017, pemerintah mengeluarkan ketentuan

19 Ratna Megawangi, Semua Berakar pada Karakter, (Jakarta : Lembaga Penerbit Fakultas Ekonomi Universitas Indonesia, 2007), hlm. 83

20 Moh. Farhan, "Meneladani Nilai-nilai Karakter Komunitas Mahasantri (Studi Pondok Pesantren Asshodiqiyah Semarang)," Jurnal Wahana Akademika, Volume 5 Nomor 1, April 2018, hlm. 69-70.

21 Kemendikbud, "Permendikbud Nomor 23 Tahun 2015 tentang Penumbuhan Budi Pekerti", simpuh. kemenag.go.id/regulasi/permendikbud_23_15.pdf diakses pada 20 Juli 2018, hlm.4 
Rencana Pelaksanaan Pembelajaran (RPP) Kurikulum 2013 yang direvisi tahun 2017.

Beberapa hal yang dikuatkan Kurikulum 2013 hasil revisi tahun 2017 yaitu (1) penguatan pendidikan karakter, (2) penguasaan literasi, dan (3) penguatan berpikir tingkat tinggi (high order thinking skills). Sementara karakter yang diperkuat dititikberatkan pada (1) religiusitas, (2) nasionalisme, (3) kemandirian, (4) gotong royong, dan (5) integritas. Sedangkan penguasaan literasi ditekankan pada literasi abad 21 yang terangkum dalam 4C, yaitu (1) creative, (2) critical thinking, (3) communicative, dan (4) collaborative. 4C tersebut sudah mencakup beberapa kompetensi berpikir tingkat tinggi. ${ }^{22}$

Dalam Permendikbud Nomor 23 Tahun 2017 tentang Hari Sekolah juga ada poin penguatan karakter. Pada implementasinya, dengan melaksanakan kegiatan keagamaan sebagaimana pada ayat (6) meliputi aktivitas keagamaan meliputi madrasah diniyah, pesantren kilat, ceramah keagamaan, katekisasi, retreat, baca tulis Alquran dan kitab suci lainnya. ${ }^{23}$

Revisi Kurikulum 2013 itu dalam implementasinya melalui beberapa hal. Pertama, penambahan dan intensifikasi kegiatan mengembangkan karakter. Kedua, menambah dan mengatur ulang alokasi waktu belajar siswa di sekolah dan luar sekolah. Ketiga, menyelaraskan dan menyesuaikan tugas pokok guru, Manajemen Berbasis Sekolah, dan fungsi Komite Sekolah dengan kebutuhan gerakan penguatan pendidikan karakter.

Berdasarkan Peraturan Presiden Republik Indonesia Nomor 87 Tahun 2017 tentang Penguatan Pendidikan Karakter (PPK), ada beberapa karakter bangsa Indonesia diajarkan dan dikuatkan kepada anak-anak. Dalam Pasal 3 Perpres Nomor 87/2017, disebutkan PPK dilaksanakan dengan nilai-nilai Pancasila dalam pendidikan karakter terutama meliputi nilainilai religius, jujur, toleran, disiplin, bekerja keras, kreatif mandiri, demokratis, rasa ingin tahu, semangat kebangsaan, cinta tanah air, menghargai prestasi, komunikatif, cinta damai, gemar membaca, peduli lingkungan, peduli sosial, dan bertanggungjawab. ${ }^{24}$

Implementasi PPK di atas, diatur melalui Permendikbud Nomor 20 Tahun 2018 tentang Penguatan Pendidikan Karakter Pada Satuan Pendidikan Formal. Pada Pasal 6 ayat 1, disebutkan penyelenggaraan PPK mengoptimalkan fungsi kemitraan Tri Pusat Pendidikan dengan pendekatan berbasis kelas, budaya sekolah, dan masyarakat.

Ayat 2 menjelaskan pendekatan berbasis kelas dilakukan dengan beberapa pendekatan. Pertama, integrasi nilai-nilai karakter dalam proses pembelajaran secara tematik/terintegrasi dalam mata pelajaran sesuai isi kurikulum. Kedua, merencanakan pengelolaan kelas dan metode pembelajaran/pembimbingan sesuai karakter peserta didik. Ketiga, evaluasi pembelajaran/ pembimbingan. Keempat, mengembangkan kurikulum muatan lokal sesuai kebutuhan dan

22 Hamidulloh Ibda, Media Pembelajaran Berbasis Wayang (Konsep dan Aplikasi), (Semarang: CV. Pilar Nusantara, 2017), hlm. 144-145.

23 Kemendikbud, "Permendikbud Nomor 23 Tahun 2017 tentang Hari Sekolah" www.sahabatkeluarga. kemdikbud.go.id diakses pada 19 Juli 2018, hlm. 6.

24 Setkab, "Peraturan Presiden Republik Indonesia Nomor 87 Tahun 2017 tentang Penguatan Pendidikan Karakter (PPK)", setkab.go.id/wp-content/uploads/2017/09/Perpres_Nomor_87_Tahun_2017.pdf diakses pada 20 Juli 2018, hlm. 4. 
karakteristik daerah, satuan pendidikan, dan peserta didik. ${ }^{25}$

Pendidikan karakter jika sudah dikuatkan di jenjang Madrasah Ibtidaiyah, maka output dari hal itu tidak hanya menjadi benih karakter dalam jiwa, namun juga pada kesuksesan akademik anak. Pendidikan karakter, dimaksudkan selain membentuk kepribadian anak untuk memiliki akhlak mulia, juga memfasilitasi anak mencapai keberhasilan akademiknya. ${ }^{26}$

Selama ini pendidikan karakter hanya dimaknai bisa diterapkan melalui mata pelajaran rumpun Pendidikan Agama Islam seperti Akidah Akhlak, Fikih, Alquran Hadis, SKI, dan lainnya. Padahal dalam mata pelajaran Bahasa Indonesia di kelas dasar atau tinggi di MI/SD juga bisa menguatkan karakter jika menggunakan pendekatan/model pembelajaran yang relevan.

Sebagai alat komunikasi, bahasa menjadi alat menguatkan karakter penutur dan mitra tuturnya. Semua bahasa yang digunakan sebagai alat komunikasi harus menerapkan nilai-nilai yang disepakati bersama. Fungsi bahasa tidak sekadar alat komunikasi, namun ciri dari derajat pengguna bahasa itu. Bahasa yang memiliki makna dan nilai bagi para penuturnya disebut bahasa santun. ${ }^{27}$

Dari penjelasan di atas, dapat disimpulkan ke dalam beberapa substansi. Pertama, pendidikan karakter merupakan usaha sadar, terencana, tersistem dalam membentuk kepribadian melalui pendidikan budi pekerti yang hasilnya terlihat dalam tindakan nyata seorang yaitu tingkah laku yang baik, jujur, bertanggung jawab, menghormati hak orang lain, kerja keras, dan sebagainya.

Kedua, ada beberapa sejumlah dasar penerapan dan penguatan pendidikan karakter. Mulai dari Permendikbud Nomor 23/2015 tentang Penumbuhan Budi Pekerti (PBP), Permendikbud No. 23/2017 tentang Hari Sekolah, Perpres Nomor 87/2017 tentang Penguatan Pendidikan Karakter (PPK), dan Permendikbud Nomor 20/2018 tentang Penguatan Pendidikan Karakter pada Satuan Pendidikan Formal. Ketiga, sebagai lembaga pendidikan dasar Islam, Madrasah Ibtidaiyah memiliki tugas berat dalam penerapan dan penguatan pendidikan karakter.

Keempat, bahasa yang diperoleh anak melalui pembelajaran bahasa menentukan karakter toleran. Penggunaan bahasa atau kata-kata kasar menjadi awal anak-anak akan berbuat intoleran. Di era siber ini hampir semua anak-anak mengenal media sosial yang mengonstruksi bahasanya. Jika tidak dikuatkan melalui pembelajaran Bahasa Indonesia, maka anak-anak usia MI/SD cenderung menggunakan bahasa kasar. Maka penguatan karakter pada anak MI/SD harus bermuatan karakter toleran sebagai vitamin yang dibutuhkan di era 21 ini.

\section{Penguatan Karakter Toleran Melalui Pembelajaran Bahasa Indonesia}

Penguatan karakter dapat dilakukan dengan tiga cara. Mulai conditioning (pengondisian), insight (pengertian), dan modelling (teladan). ${ }^{28}$ Karakter dan pendidikan karakter memiliki perbedaan. Karakter berasal dari bahasa Yunani, charassein yang artinya “mengukir”. Membentuk

25 Kemendikbud, "Permendikbud Nomor 20 Tahun 2018 Tentang Penguatan Pendidikan Karakter Pada Satuan Pendidikan Formal,” www.websiteedukasi.com diunduh pada 20 Juli 2018, hlm.5-6.

26 Ismail SM, "Integrasi Pendidikan Karakter Anak Usia Dini Melalui Model Pembelajaran Berbasis Beyon Centers and Circle Time (BCCT)," Jurnal Wahana Akademika, Vol. 15. No.1. April 2013, Hlm. 43.

27 Sofyan Sauri, Pendidikan Berbahasa Santun, (Bandung: PT. Genesindo, 2006), hlm. 55.

28 Bimo Walgito, Pengantar Psikologi Umum, (Yogyakarta: Fakultas Psikologi UGM, 1994), Hlm.79. 
karakter diibaratkan mengukir batu permata atau permukaan besi keras. Selanjutnya, berkembang pengertian karakter yang diartikan sebagai tanda khusus atau pola perilaku. Di Indonesia sendiri, untuk menguatkan karakter dimasukkan dan diregulasikan melalui program Penguatan Pendidikan Karakter (PPK).

Fungsi pendidikan karakter meliputi pengembangan, perbaikan dan penyaring. Pertama, pengembangan potensi peserta didik untuk berperilaku baik, terutama bagi peserta didik yang telah memiliki sikap dan perilaku yang mencerminkan karakter bangsa. Kedua, memperkuat kiprah pendidikan nasional untuk bertanggung jawab dalam pengembangan potensi peserta didik. Ketiga, menyeleksi budaya bangsa sendiri dan budaya bangsa lain yang tidak sesuai nilainilai karakter bermartabat. ${ }^{29}$

Dalam pembelajaran Bahasa Indonesia di Madrasah Ibtidaiyah, bisa menerapkan pilar UNESCO. Tujuan pendidikan sesuai pilar itu meliputi learning to know (belajar untuk tahu), learning to be (belajar untuk menjadi diri sendiri), learning to do (belajar untuk melakukan) dan to live together (belajar untuk hidup bersama). ${ }^{30}$

Toleransi berasal dari kata tolerance yang artinya membiarkan. Dalam Bahasa Indonesia, toleransi merupakan sifat/sikap toleran, mendiamkan, membiarkan. ${ }^{31}$ Toleransi merupakan sikap membiarkan, mengakui dan menghormati keyakinan orang lain tanpa memerlukan persetujuan. ${ }^{32}$ Sementara dalam Bahasa Arab, toleransi diambail dari samahah, atau tasamuh yang pada dasarnya sama seperti aljud (kemuliaan), sa’at alsadr (lapang dada) dan tasahul (ramah, suka memaafkan). ${ }^{33}$

Toleransi juga berasal dari bahasa Latin, tolerantia yang artinya kelonggaran, kelembutan hati, keringanan dan kesabaran. ${ }^{34}$ Nilai-nilai dan konsep tasamuh atau toleransi dalam Islam bersumber dari Alquran dan hadis. Kaidah toleransi dalam Islam berasal dari ayat Alquran "laa ikraaha fiddiin” yang berarti tidak ada paksaan dalam agama, namun tidak menafikan unsur dakwah Islam yang sifatnya mengajak, bukan memaksa. ${ }^{35}$

Penguatan karakter toleran sudah dilegitimasi pemerintah dalam program PPK. Dari tahun ke tahun, rumusan pendidikan karakter selalu berubah meyesuaikan zaman. Secara umum, dalam penerapan pendidikan karakter, karakter toleransi atau toleran di sini, bermakna sikap dan tindakan yang menghargai perbedaan agama, suku, etnis, pendapat, sikap, dan tindakan

29 Sri Judiani, "Implementasi Pendidikan Karakter di Sekolah Dasar Melalui Penguatan Pelaksanaan Kurikulum,” Jurnal Pendidikan dan Kebudayaan, Vol. 16, Edisi Khusus III, Oktober 2010, Hlm. 282-283.

30 H.M. Nur Hasan, "Model Pembelajaran Berbasis Pondok Pesantren dalam Membentuk Karakter Siswa di Pondok Pesantren Raoudhotut Tholibin Rembang Jawa Tengah," Jurnal Wahana Akademika, Volume 3 Nomor 2, Oktober 2016, hlm. 96.

31 Departemen Pendidikan Nasional, Kamus Besar Bahasa Indonesia, (Jakarta: Balai Pustaka, 1989), hlm. 955.

32 A. S. Hornby, Oxford Advanced Learners Dictionary of Current English, (London: Oxford University Press, Cet. ke-23, 1986), hlm. 909

33 Ahmad Warson Munawwir, Kamus al-Munawwir Arab Indonesia Terlengkap, (Surabaya: Pustaka Progresif, Edisi ke-2. Cet. Ke-14, 1997), hlm. 657.

34 Zuhairi Misrawi, Al-Qur'an Kitab Toleransi, (Jakarta : Pustaka Oasis, 2007), hlm. 161.

35 Bustanul Arifin, "Implikasi Prinsip Tasamuh (Toleransi) Dalam Interaksi Antar Umat Beragama“, Jurnal Fikri, Vol. 1, No. 2, Desember 2016, hlm. 409. 
orang lain yang berbeda dari dirinya. ${ }^{36}$

Dalam konsep Islam, pendidikan karakter substansinya sama dengan pendidikan akhlak. Pendidikan karakter bagi siswa SD sangat urgen diterapkan. Pendidikan karakter dalam Islam, khususnya di SD, bisa diterapkan berbasis Alquran dan hadis dengan pendekatan menyeluruh. Mulai dari teladan, arahan, dorongan, kontinu, pengarahan, pengingatan, pengorganisasian, dan pendekatan hati. ${ }^{37}$

Domain pendidikan budi pekerti harus mengisi jiwa peserta didik dengan moral dan akhlak agar bertingkah laku baik, dan urgen diwujudkan dalam kurikulum SD. Namun pengimplementasiannya jauh lebih penting manakala disertai adanya upaya pembiasaan, pengamalan, pengkondisian lingkungan dan keteladanan.

Dalam penerapan pendidikan budi pekerti, sekolah sebaiknya didorong membuat terobosan mekanisme baru sebagai wahana internalisasi nilai terhadap peserta didik agar menjadi lebih menarik. Pertama, tugas-tugas yang diberikan senantiasa mengikutsertakan orang tua sebagai guru sebagai role model. Kedua, penghargaan bagi peserta didik berbudi pekerti tinggi. Ketiga, model pembelajaran budi pekerti yang dikaitkan produktivitas, seperti skill manajemen, speed reading, kepemimpinan, karya bermanfaat bagi sesama, dan lainnya. Keempat, hadirnya konsep hukum di sekolah yang dapat memberi kesadaran hukum. ${ }^{38}$

Tidak hanya dalam mata pelajaran khusus, namun juga dalam sejumlah kegiatan sekolah secara regular, dan kepala sekolah juga memimpin dan menggerakkan seluruh komponen sekolah secara manajerial. ${ }^{39}$ Artinya, peran guru dan kepala sekolah menjadi kiblat/contoh karakter pada anak selain melalui pembelajaran di ruang kelas.

Dari peta karakter di atas, di era Revolusi Industri 4.0 ini, salah satu karakter yang urgen dikuatkan adalah karakter toleran, terutama di jenjang MI/SD sebagai peletak fondasi kecerdasan intelektual, spiritual, dan emosional pada anak. Setelah mengenal bentuk toleransi beragama, maka harus dispesifikkan pada karakter dalam dunia bahasa.

Dalam Alquran ada enam prinsip dalam berbahasa. Pertama, berbicara benar. Kedua, berbicara menyedapkan hati, tidak menyakiti perasaan sesuai kriteria kebenaran, jujur, tidak bohong, dan berpura-pura. Ketiga, berbicara dengan ungkapan mengena, mencapai sasaran dan tujuan. Keempat, berbicara dengan bahasa baik, pantas dan tidak mengecewakan. Kelima, menggunakan kata-kata mulia, berisi, bertujuan baik, dan mencerminkan akhlak terpuji. Keenam, berbicara lembut. ${ }^{40}$

36 Sri Judiani, "Implementasi Pendidikan Karakter di Sekolah Dasar Melalui Penguatan Pelaksanaan Kurikulum,"... hlm.284.

37 Ani Nur Aeni, "Pendidikan Karakter untuk Siswa SD dalam Perspektif Islam", Jurnal Mimbar Sekolah, Volume 1 Nomor 1, April 2014, Hlm. 50.

38 Sutjipto, "Pendidikan Budi Pekerti Pada Kurikulum Sekolah Dasar", Jurnal Pendidikan dan Kebudayaan, Vol. 20, Nomor 4, Desember 2014, Hlm.496.

39 Agus Salim Chamidi dan Bahrun Ali Murtopo, "Manajemen Pendidikan Karakter Mabadi Khaira Ummah di SMK Maarif 2 Gombong," Jurnal Wahana Akademika, Volume 5 Nomor 1, April 2018, hlm. 18.

40 MD Dahlan, "Pengembangan Kepribadian Mahasiswa Melalui Mata Kuliah Pengembangan Kepribadian", Makalah, 30 Juli 2001, hlm.9 
Karakter santun dalam berbahasa harus dikuatkan. Melalui kata-kata atau bahasa menjadi landasan dalam perbuatan. Jika bahasanya halus, santun, tentu yang muncul spirit toleransi. Kesantunan berbahasa dapat memperkokoh keakraban, dan menjadi alat mengurangi potensi perpecahan, intoleransi dalam interaksi personal maupun sosial. ${ }^{41}$

Kesantunan, toleransi, dan kelembutan berbahasa menentukan tindakan santun, toleran, dan kelembutan tindakan. Dalam teori tindak tutur, menjelaskan ujaran-ujaran yang dibuat penutur dalam peristiwa komunikasi tertentu adalah tindakan (acts atau actions). Teori ini menegaskan to say something is to do something (mengatakan sesuatu adalah melakukan sesuatu). ${ }^{42}$

Dalam dunia bahasa, kesantunan berbahasa disebut "kesantunan linguistik" yang terefleksi dalam ujaran bermakna yang dikomunikasikan penutur pada mitra tutur. Bagaimana penutur mengujarkan pesannya kepada mitra tuturnya dipengaruhi berbagai faktor, baik internal maupun eksternal. Faktor internal yang berpengaruh adalah keinginan penutur bersikap santun terhadap petutur. Hal ini berkaitan dengan usahanya memilih bentuk ujaran sesuai keinginannya dengan mempertimbangkan faktor peristiwa komunikasi tersebut. ${ }^{43}$

Selain fungsi informasi, Bahasa Indonesia memiliki fungsi ekspresi diri, adaptasi dan integrasi, serta fungsi kontrol sosial. Fungsi khususnya, Bahasa Indonesia untuk alat pemersatu berbagai suku yang memiliki latar belakang budaya, bahasa, dan wadah penampung kebudayaan. ${ }^{44}$ Di sinilah urgensi penguatan karakter toleran menjadi strategis diimplementasikan dalam pembelajaran bahasa.

Bahasa santun menjadi sumber sifat dan sikap toleransi. Anak-anak khususnya jenjang MI/SD harus jauh dari kerusakan bahasa yang berakibat fatal pada perbuatan seperti bullying. Perundungan merupakan perilaku tidak menyenangkan secara sengaja dan berulang sehingga seorang menjadi trauma dan tidak berdaya.

Perundungan fisik mulai dari mendorong, meninju/memukul, menjegal, mengancam, menjambak. Perundungan verbal meliputi memberikan julukan tidak menyenangkan, menghina, menyindir mengancam, dan menyebar gosip. Jika dibiarkan akan berpuncak pada perundungan sosial seperti mengucilkan, mengabaikan, memalak, memfitnah. Pemicu perundungan sosial dipengaruhi kerusakan bahasa di media sosial dalam bentuk perundungan dunia maya. Mulai dari memperolok di medsos, mengubah foto menjadi tidak semestinya, dan menyebar pesan teror. ${ }^{45}$

41 Robin Lakoff, "The Logic of Politeness: Or, Minding Your P's And Q's", in Corum, C. et al. (eds). Papers from the Ninth Regional Meeting of the Chicago Linguistic Society, Chicago Linguistic Society, 1973, hlm.297.

42 John Langshaw Austin, How to Do Things with Words, Second Edition, (Cambridge, Mass: Harvard University Press, 1975), Hlm.12.

43 I Ketut Seken, "Penggunaan Peranti Pendukung untuk Melembutkan Ujaran: Sebuah Kasus Kesantunan Bahasa Bali", Jurnal PRASI, Vol. 8 No. 15, Januari - Juni 2013, Hlm.33.

44 Puji Santosa, dkk, Materi dan Pembelajaran Bahasa Indonesia SD Cetakan ke-18, (Jakarta: Universitas Terbuka, 2011), Hlm.5-6.

45 Diena Haryana, dkk, Seri Pendidikan Orang Tua: Ayo, Bantu Anak Hindari Perundungan, (Jakarta: Direktorat Pembinaan Pendidikan Keluarga Direktorat Jendral Pendidikan Anak Usia Dini dan Pendidikan Masyarakat Kementerian Pendidikan dan Kebudayaan, 2017), hlm.1-6. 
Pembentukan karakter toleran ditentukan pembelajaran bahasa. Jika pembelajaran bahasanya santun, toleran, maka akan berdampak pada perilaku atau tindakan toleran pula. Untuk itu, perlu syarat pembelajaran bahasa santun sesuai tahapannya.

Ada enam maksim kesantunan yang diformulasikan. Pertama, maksim kearifan (tact maxim). Buatlah kerugian orang lain sekecilnya, dan keuntungan orang lain sebesarnya. Kedua, maksim kedermawanan (generosity maxim). Caranya, membuat keuntungan diri sendiri sekecilnya dan kerugian diri sendiri sebesarnya. Ketiga, maksim pujian (approbation maxim). Caranya, kecamlah orang lain sesedikitnya, dan pujilah orang lain sebanyaknya.

Keempat, maksim kerendahan hati (modesty maxim). Caranya, puji diri sendiri sesedikitnya, dan orang lain sebanyaknya. Kelima, maksim kesepakatan (agreement maxim). Usahakan agar ketaksepakatan antara diri sendiri dan orang lain terjadi sesedikitnya, dan kesepakatan antara diri sendiri dan orang lain terjadi sebanyaknya. Keenam, maksim simpati (sympathy maxim). Caranya, mengurangi rasa antipati antara diri sendiri dan orang lain sekecilnya dan meningkatkan rasa simpati sebanyak-banyaknya antara diri sendiri dan orang lain. ${ }^{46}$

Dalam penguatan karakter toleran melalui pembiasaan berbahasa santun sangat urgen diterapkan dalam pembelajaran Bahasa Indonesia. Prinsipnya, harus ada transfer nilai dan budi pekerti (akhlakul karimah), berupa proses pembudayaan (enkulturasi) peserta didik sehingga melahirkan keadaban (civility). Realitasnya, pendidikan karakter masih minim disiapkan secara terencana pada lembaga pendidikan. ${ }^{47}$

Dari penjelasan di atas, dapat disimpulkan ke dalam beberapa inti. Pertama, penguatan karakter toleran dalam pembelajaran Bahasa Indonesia bisa diimplementastikan dengan pengondisian, pengertian, dan teladan. Kedua, fungsi pendidikan karakter meliputi pengembangan, perbaikan dan penyaring. Dalam implementasinya, karakter toleran harus melahirkan tindakan toleransi, membiarkan, mengakui dan menghormati keyakinan orang lain tanpa memerlukan persetujuan. Toleransi atau tasamuh bermuara pada nilai kemuliaan, lapang dada, ramah, dan suka memaafkan.

Ketiga, indikator berbahasa santun yaitu berbicara benar, menyedapkan hati, tidak menyakiti perasaan sesuai kriteria kebenaran, jujur, tidak bohong, dan tidak berpura-pura. Selanjutnya berbicara dengan ungkapan mengena, mencapai sasaran, berbicara dengan bahasa baik, pantas dan tidak mengecewakan orang. Lalu menggunakan kata-kata mulia, berisi, bertujuan baik, terpuhi, dan mencerminkan akhlak terpuji, dan berbicara lembut.

Keempat, dalam dunia bahasa, kesantunan berbahasa disebut kesantunan linguistik. Berbahasa santun, toleran, ramah, menjadi kunci melahirkan karakter toleran. Salah satu strateginya bisa dilaksanakan dalam pembelajaran Bahasa Indonesia dengan menekankan karakter toleran.

Kelima, ada enam tahapan kesantunan dalam berbahasa. Mulai dari maksim kearifan, kedermawanan, pujian, kerendahan hati, kesepakatan, dan maksim simpati. Keenam, penguatan

46 Geoffrey Neil Leech, Principles of Pragmatics, (London: Longman, 1983), Hlm. 119.

47 Setyoadi Purwanto, Pendidikan Karakter Melalui Seni, (Yogyakarta: Pustaka Pelajar, 2016), Hlm. 175. 
karakter toleran bisa dimulai dengan pembiasaan berbahasa santun yang bisa diterapkan dalam pembelajaran Bahasa Indonesia. Prinsipnya, transfer budi pekerti, berupa proses pembudayaan sehingga melahirkan keadaban.

\section{Kerusakan Bahasa dan Penguatan Pembelajaran Bahasa Indonesia}

Bahasa menjadi indikator karakter seorang. Semakin batik tutur katanya, maka ia merepresentasikan baik akhlaknya. Pepatah Jawa menyebut ajining diri ono ing lati, ajining saliro ono ing busono yang artinya harga diri seorang terletak pada tutur kata yang yang dikatakannya, sedangkan keberhargaan tubuh tampak dalam busananya. ${ }^{48}$ Akan tetapi, di era siber ini katakata anak usai MI/SD sudah mengalami banyak kerusakan.

Dari analisis yang ditemukan, ada beberapa kosakata sering dipilih anak-anak dan remaja khususnya usia MI/SD. Seperti contoh assalamu alaikum, masyaallah, mohon maaf, gimana, goblog, bokap, nyokap, anjing, anjir, terima kasih, persimi, setan, monyet, bismillah, subhanallah, maneh, sukur, aing, sia, elu, gue, alhamdulillah, bete, bolot, astaga, boloho, belengong, jurig, gila, edan, kamu mah, dan lainnya. ${ }^{49}$ Kosakata itu bisa melahirkan kebaikan atau keburukan jika tidak diarahkan kepada karakter toleran.

Kesantunan dan ketidaksantunan berbahasa erat dengan tindakan. Kata-kata diucapkan anak tidak sekadar kata, melainkan menjadi isyarat menggambarkan simbol budaya dan karakter. ${ }^{50}$ Semakin kasar bahasa anak, ia cenderung intoleran, karena kata-kata yang diucapkan tidak hanya masalah bahasa, namun juga rasa dan jiwa.

Anak-anak usia MI/SD di desa saat ini tidak jauh berbeda dengan di kota-kota. Mereka kebanyakan sudah biasa menggunakan bahasa "semrawut" dan tidak bisa membedakan, mana bahasa sendiri dan bahasa impor, mana bahasa asli dan asing. Pengaruh teknologi dengan adanya gagdet (gawai), internet, media sosial membuat anak-anak semakin kacau dalam berbahasa.

Banyak sekali bahasa ibu (bahasa pertama) yang terdiri atas bahasa daerah/lokal dan Bahasa Indonesia rusak dan digantikan bahasa arbitrer (mana suka) dan bahasa slang (tidak baku/ musiman). Seperti contoh penggunaan kata-kata saya, aku, inyong, kulo, sira, abdi, kuring, karena faktor globalisasi semakin semrawut menjadi gue, gua, ane, eke, aqiu, dan lainnya.

Kemudian penggunaan kata-kata kamu, jenengan, rika, koen, menjadi lo, lu, ente, bro, guys, sis, yu, dan lainnya. Penggunaan gawai dan media sosial juga menjadi pengaruh rusaknya bahasa pada anak-anak bahkan orang dewasa. Seperti kata aku menjadi aq, q, qu, ak, ku, aqiu, aqyu, gw, w, sedangkan kata kamu menjadi lo, lu, u, yu, amu, km, kmu, dan lainnya.

Kerusakan lain juga terjadi pada komunikasi maya anak-anak. Budaya mengejek, hate speech (ujaran kebencian) sangat berdampak negatif pada anak. Mereka semakin berani dan lantang secara lisan dan tulisan mengatakan asu, asem, babu, fuck you, cukimai, mother fuck, jancuk, picek, perek, pukimak, kakekane, matane dan lainnya. Meski ada unsur bahasa Jawa,

48 V. Naniek Risnawati, "Busana Mencerminkan Kepribadian," Jurnal STIE Semarang, Vol 6, No 1, Edisi Februari 2014, Hlm. 18.

49 Sofyan Suari, Pendidikan Berbahasa Santun,... hlm. 84.

50 Sofyan Suari, Pendidikan Berbahasa Santun,... hlm. 92. 
Sunda, Indonesia atau lainnya, namun bahasa itu memiliki tempat dan kodifikasinya. Sebab, orang Indonesia memiliki bahasa-bahasa kritikan yang harus disesuaikan pada tempatnya. ${ }^{51}$

Penggunaan bahasa kasar cenderung melahirkan sikap intoleran, bahkan permusuhan. Padahal dalam bahasa, anak-anak harus dikenalkan dengan kode bahasa, budaya, dan sastra yang bisa dikenalkan dalam pembelajaran Bahasa Indonesia sesuai pendekatan diterapkan guru. Pendidikan karakter dalam pembelajaran Bahasa Indonesia sangat ditentukan "pengalaman pembelajaran" daripada sekadar pemahaman. Membentuk karakter dalam pembelajaran harus menekankan aktivitas positif. ${ }^{52}$

Dalam menumbuhkan sikap toleransi, dalam pembelajaran juga bisa menerapkan "pertanyaan toleran" yang dilakukan guru. Misalnya, "Apakah selama ini saua bersedia menerima saran orang?" Pertanyaan lain, misalnya, "Apakah selama ini saya termasuk orang yang tidak egois dan selalu bersedia mendengarkan saran dan nasihat orang lain?" 53 Pertanyaan seperti ini harus menumbuhkan sikap toleransi yang bisa dimulai dalam pembelajaran Bahasa Indonesia.

Bahasa memiliki peran strategis dalam perkembangan intelektual, sosial, dan emosional peserta didik. Pembelajaran Bahasa Indonesia diharapkan membantu siswa mengenal siapa dirinya, lingkungannya, budayanya, dan budaya orang lain, mengemukanan gagasan dan perasaannya. ${ }^{54}$

Pembelajaran Bahasa Indonesia pada lembaga pendidikan formal mulai dari SD-SMA tidak lagi mengajarkan bahasa secara teoretis, akan tetapi untuk berkomunikasi dan membentuk karakter. Pembelajaran bahasa yang bertujuan agar siswa berkomunikasi menggunakan bahasa santun dan sesuai faktor-faktor penentu komunikasi. Faktor-faktor itu meliputi siapa berbicara dengan siapa, tujuan, tempat, waktu, konteks kebudayaan, suasana, jalur dan media, dan peristiwa bebahasa. ${ }^{55}$

Dari penjelasan di atas, simpulannya adalah semua kerusakan bahasa pada anak berpotensi menjadikan anak intoleran. Mereka cenderung kasar, kaku, keras, intoleran yang pada puncaknya menjadi radikal. Ucapan merupakan representasi isi pikiran dan simbol budaya. Solusinya yaitu menguatkan pembelajaran Bahasa Indonesia dengan muatan kesantunan yang bisa dilakukan dengan pendekatan yang tepat.

\section{Implementasi Pendekatan Whole Language}

Keberhasilan pendidikan karakter toleran sangat ditentukan dengan keberhasilan suatu pembelajaran. Dalam praktiknya, keberhasilan pembelajaran ditentukan pendekatan dilakukan guru dalam kegiatan di kelas. Guru harus menyesuaikan pendekatan pembelajaran bahasa sesuai

51 Hamidulloh Ibda, "Urgensi Pemertahanan Bahasa Ibu di Sekolah Dasar”, ... Hlm.197.

52 Nurla Isna Aunillah, Panduan Menerapkan Pendidikan Karakter di Sekolah, (Jogjakarta: Laksana, 2011), Hlm. 110.

53 Nurla Isna Aunillah, Panduan Menerapkan Pendidikan Karakter di Sekolah,... Hlm.122.

54 Nurul Hidayah, "Pendekatan Pembelajaran Bahasa Whole Language," Jurnal Terampil, Vol. 3, Nomor 3, Desember 2014, Hlm. 77.

55 Sri Utari Subyakto dan Nababan, Metodologi Pengajaran Bahasa, (Jakarta: Gramedia Pustaka Utama, 1993), Hlm. 93. 
realitas sosial dan lingkungannya. Salah satu pendekatan pembelajaran Bahasa Indonesia yang selalu relevan adalah whole language. ${ }^{56}$

Whole language merupakan pendekatan pembelajaran yang menekankan kebebasan guru dalam pembelajaran bahasa. Guru mudah menggunakan pendekatan whole language dalam pembelajaran bahasa apabila bahasa diajarkan digunakan dalam aktivitas sehari-hari sehingga komponen bahasa menjadi berarti. ${ }^{57}$ Whole language merupakan pendekatan pembelajaran bahasa secara utuh, tidak terpisah-pisah dan bisa menguatkan pemahaman anak akan sebuah konsep/teori secara utuh. ${ }^{58}$

Whole languange menyediakan lingkungan belajar di mana siswa berpartisipasi dalam pengalaman bahasa berarti. Melalui proses membangun bahasa untuk berkomunikasi, siswa mengembangkan kemampuan mendengarkan, berbicara, membaca, dan menulis dengan cara alami. ${ }^{59}$ Whole language bisa disebut pembelajaran Bahasa Indonesia terpadu. Caranya, dalam pembelajaran Bahasa Indonesia dilaksanakan terpadu antara membaca, mendengarkan, menulis, dan berbicara. ${ }^{60}$

Whole language didasari faham konstruktivis yang bisa diarahkan pada output keterampilan berbasa yang toleran. Dalam whole language, bahasa diajarkan secara utuh, tidak terpisah-pisah, mulai menyimak, wicara, membaca, dan menulis diajarkan secara terpadu sehingga siswa melihat bahasa sebagai suatu kesatuan. ${ }^{61}$ Pembelajaran dengan pendekatan ini menekankan pada empat keterampilan berbahasa, yaitu menyimak/mendengarkan, membaca, menulis, dan berbicara. Sehingga, apa yang dibaca, didengar, dan ditulis anak tentang suatu konsep, wacana, atau teori menjadi komprehensif dipahami anak dan tidak parsial.

Keampuhan Pendekatan whole language banyak dibuktikan beberapa negara. Whole language dapat diterapkan dalam pembelajaran bahasa dan sastra Indonesia di SD. Prinsip dan penggarapan proses pembelajarannya diwarnai progresivisme dan konstruktivisme, yang menyatakan siswa membentuk sendiri pengetahuannya melalui peran aktif dalam belajar secara utuh (whole) dan terpadu (integrated). ${ }^{62}$

Routman dan Froese (1991) menjelaskan ada delapan komponen whole language. Mulai reading aloud (membaca keras), sustained silent reading (membaca diam), shared reading (membaca bersama), journal writing (menulis jurnal), guided reading (membaca terbimbing), guided writing (menulis terpandu), independent reading (membaca independen), dan independent writing (menulis independen).

Dalam menerapkan whole language di kelas, guru harus melibatkan semua keterampilan

56 Suratinah dan Teguh Prakoso, "Pendekatan Pembelajaran Bahasa dan Sastra Indonesia SD," dalam Materi dan Pembelajaran Bahasa Indonesia SD cetakan ke-18, (Jakarta: Universitas Terbuka, 2011), hlm. 29.

57 V.F. Froese (Ed), Whole-language: Practice and Theory, (Scarborough, ON: Prentice-Hall Canada, Inc, 1990), Hlm.3.

58 Herlin Nur Rofiqoh, "Model Pembelajaran Membaca Cerpen dengan Menggunakan Pendekatan Whole Languange pada Siswa Kelas Viii Smpn 1 Tarogong tahun Ajaran 2011/2012,” Makalah, Prodi Pendidikan Bahasa dan Sastra Indonesia STKIP Siliwangi Bandung tahun 2012, Hlm.3.

59 Mary Lynn Redmond, "The Whole Language Approach in the FLES Classroom: Adapting Strategies to Teach Reading and Writing", Article Foreighn Language Annals, American Council on the Teaching of Foreign Languages (ACTFL), October 1994, Hlm.428.

60 H.D Brown, Principle of Language Learning and Teaching, (London: Prentice Hall International Limited, 1997), Hlm. 25.

61 Suratinah dan Teguh Prakoso, "Pendekatan Pembelajaran Bahasa dan Sastra Indonesia SD".... Hlm.2.16.

62 Suratinah dan Teguh Prakoso, "Pendekatan Pembelajaran Bahasa dan Sastra Indonesia SD”.... Hlm.2.2. 
dan unsur bahasa dalam kegiatan pembelajaran secara utuh. ${ }^{63}$ Ada tujuh ciri kelas berbasis whole language. Pertama, kelas penuh barang cetakan. Kedua, guru berperan sebagai model. Guru menjadi contoh perwujudan aktivitas berbahasa ideal, dalam kegiatan membaca, menulis, menyimak, dan berbicara.

Ketiga, peserta didik bekerja dan belajar sesuai tingkat kemampuannya. Keempat, peserta didik berbagi tanggung jawab dalam pembelajaran. Peran guru di kelas sebagai fasilitator dan peserta didik mengambil alih beberapa tanggung jawab yang biasanya dilakukan guru. Peserta didik, membuat kumpulan kata (words blank), melakukan brainstorming, dan mengumpulkan fakta.

Kelima, peserta didik terlibat aktif dalam pembelajaran bermakna. Peserta didik dalam pembelajaran mengembangkan rasa tanggungjawab dan tidak bergantung. Keenam, di kelas whole language peserta didik berani mengambil risiko dan bebas bereksperimen. Guru di kelas hanya menyediakan kegiatan belajar dalam berbagai tingkat kemampuan sehingga semua peserta didik berhasil. ${ }^{64}$ Cara ini strategis dalam mengonstruksi pemahaman anak tentang teori, konsep, atau pengetahuan tertentu.

Penerapan whole language dapat dilakukan dengan strategi melalui beberapa tahapan berbasis bahasa santun, halus, dan toleran di dalam kelas seperti tabel di bawah ini ${ }^{65}$ :

\begin{tabular}{|l|l|l|l|}
\hline No & $\begin{array}{l}\text { Langkah } \\
\text { Pembelajaran }\end{array}$ & Kegiatan Guru & Kegiatan Peserta Didik \\
\hline 1 & Prakondisi & $\begin{array}{l}\text { Mengondisikan peserta didik untuk siap melakukan } \\
\text { pembelajaran tentang bahasa santun, toleran, } \\
\text { halus. Guru mengaitkan kejadian di sekitar seperti } \\
\text { radikalisme, terorisme, dan ujaran kebencian } \\
\text { terhadap urgensi berbahasa halus, santun, dan } \\
\text { toleran }\end{array}$ & $\begin{array}{l}\text { Menyimak dan merespon agar } \\
\text { mereka ikut andil dalam masalah/ } \\
\text { fakta di lapangan terkiat urgensi } \\
\text { berbahasa santun }\end{array}$ \\
\hline 2 & Pembelajaran & $\begin{array}{l}\text { Mengemukakan kosakata bahasa santun, toleran, } \\
\text { halus. } \\
\text { Merangkai dalam kalimat, mengembangkan } \\
\text { arti dari kosakata dan kalimat tersebut, serta } \\
\text { menjelaskan cara pengungkapan disertai dan } \\
\text { suara, gerak, isyarat, sesuai dengan norma yang } \\
\text { disepakati masyarakat bahasa }\end{array}$ & $\begin{array}{l}\text { Menyimak, menghayati, menirukan } \\
\text { kalimat, nada, suara, dan menirukan } \\
\text { gerak yang dilakukan guru }\end{array}$ \\
\hline 3 & Mengecek suasana & $\begin{array}{l}\text { Mengetes suara kelas dengan pengamatan dan } \\
\text { penghayatan terhadap gerak dan mimik peserta } \\
\text { didik }\end{array}$ & $\begin{array}{l}\text { Berbahasa dengan mimik, nada, } \\
\text { suara, dan gerak sesuai instruksi guru }\end{array}$ \\
\hline 4 & Penguatan & $\begin{array}{l}\text { Memberikan penguatan tentang pengetahuan } \\
\text { bahasa yang disampaikan, nilai, norma, yang } \\
\text { melekat pada pada kosakata dengan memberikan } \\
\text { penekanan pada momen-momen tertentu yang } \\
\text { dianggap penting }\end{array}$ & $\begin{array}{l}\text { Merepon dengan jawaban dan } \\
\text { menulis rangkuman tiap kata yang } \\
\text { didiskusikan guru }\end{array}$ \\
\hline
\end{tabular}

63 Suratinah dan Teguh Prakoso, "Pendekatan Pembelajaran Bahasa dan Sastra Indonesia SD"... Hlm.2.4.

64 Suratinah dan Teguh Prakoso, "Pendekatan Pembelajaran Bahasa dan Sastra Indonesia SD".... Hlm.2.102.12 .

65 Sofyan Sauri, Pendidikan Berbahasa Santun,... Hlm.138-139. 


\begin{tabular}{|l|l|l|l|}
\hline 5 & Evaluasi & $\begin{array}{l}\text { Mengajukan pertanyaan singkap terhadap materi } \\
\text { bahasa dan kesantunan, toleran, dan aspek } \\
\text { kelembutan pada bahasa yang diajarkan }\end{array}$ & $\begin{array}{l}\text { Menjawab pertanyaan dengan kata- } \\
\text { kata, gerak, dan perilaku }\end{array}$ \\
\hline 6 & $\begin{array}{l}\text { Menyimpulkan dan } \\
\text { menutup }\end{array}$ & $\begin{array}{l}\text { Mendorong peserta didik untuk dapat } \\
\text { menyimpulkan isi pembelajaran bahasa, dan } \\
\text { mengarahkan kepada simpulan yang benar sesuai } \\
\text { dengan tujuan }\end{array}$ & $\begin{array}{l}\text { Menjawab pertanyaan, dan } \\
\text { menyimpulkan bersama tentang nilai- } \\
\text { nilai karakter toleran, halus, santun } \\
\text { yang melekat pada kosakata }\end{array}$ \\
\hline
\end{tabular}

Dari tabel di atas, bisa dikembangkan guru sesuai materi dan karakter belajar peserta didik. Materi yang kontekstual lebih mengena, dan jika tematik, maka bisa dihubungkan dengan mata pelajaran lainnya. Mengapa perlu dihubungkan? Sebab, aspek-aspek penting yang menyangkut pengalaman dan keterampilan berbahasa dalam pembelajaran bahasa dan sastra Indonesia di MI/SD kurang diperhatikan, bahkan strategi dan metode pembelajarannya pun masih bersifat tradisional dan kurang inovatif.

Di sekolah, pembelajaran bahasa dan sastra Indonesia diarahkan meningkatkan kemampuan mereka berkomunikasi dalam bahasa Indonesia dengan benar dan baik, secara lisan dan tertulis. Pembelajaran Bahasa Indonesia berfungsi pula sebagai sarana membantu siswa mengemukakan gagasan dan perasaan, berpartisipasi dalam masyarakat dengan bahasa tersebut, menemukan serta menggunakan kemampuan analitis dan imajinatif. ${ }^{66}$

Anak-anak harus diajarkan pemaknaan pada teks/kata, mulai dari tekstual, kontekstual, dan bahkan interteksual. Anak-anak harus dikenalkan setiap kata menyimpan karakter, nilai, dan budaya. Misalnya, dalam memahami kata "radikalisme" jika tidak tepat, maka mereka justru menjadi pelaku radikalisme itu sendiri. Dalam whole language, konsep seperti ini bisa dikupas lebih dalam karena peserta didik aktif, memahami secara komprehensif dari aspek menyimak, membaca, menulis, dan berbicara.

Kesuksesan pembelajaran Bahasa Indonesia sangat ditentukan pendekatan yang dipilih. Sejak kurikulum 1984 sampai sekarang, model pembelajaran Bahasa Indonesia telah bergeser menjadikan peserta didik sebagai titik pusat (learner centered). Titik pembelajaran Bahasa Indonesia tidak sekadar aspek bahasa yang dipelajari, melainkan pada aspek komunikasi dan budaya siswa. ${ }^{67}$ Penerapan pendekatan whole language dapat meningkatkan kualitas proses pembelajaran dan pengalaman siswa dengan tahapan lebih kompleks dan menyeluruh. ${ }^{68}$

Dari penjelasan di atas, dapat disimpulkan ke dalam beberapa substansi. Pertama, pendekatan whole language menjadi pendekatan pembelajaran bahasa yang menyajikan pengajaran bahasa secara utuh, tidak terpisah-pisah. Inti dari pendekatan ini, keterampilan berbahasa dan komponen bahasa seperti tata bahasa dan kosakata disajikan utuh, bermakna,

66 Rini Dwi Susanti, "Pembelajaran Apresisasi Sastra di Sekolah Dasar", Jurnal Elementary, Vol. 3 No. 1, Januari-Juni 2015, Hlm. 139.

67 Subana dan Sunarti, Strategi Belajar Mengajar Bahasa Indonesia, Cetakan III, (Bandung: CV. Pustaka Setia, 2011), Hlm.61.

68 Hariyanto, "Pendekatan Whole Language Sebagai Upaya Peningkatan Kemampuan Menulis Pengalaman dalam Pembelajaran Bahasa Indonesia," Tesis, Program Pascasarjana Fakultas Pendidikan Bahasa Indonesia Universitas Sebelas Maret Surakarta tahun 2009, hlm. xv. 
dan dalam situasi nyata.

Kedua, dalam whole language, guru harus memahami dulu komponen-komponen whole language agar pembelajaran maksimal. Mulai dari reading aloud, journal writing, sustained silent reading, shared reading, guided reading, guided writing, independent reading, dan independent writing. Ketiga, kelas berbasis whole language merupakan kelas yang kaya dengan barang cetak seperti buku, koran, majalah, dan buku petunjuk. Kelas whole language dibagibagi dalam sudut yang memungkinkan siswa melakukan kegiatan individual di sudut-sudut itu. Kelas whole language menerapkan penilaian berbasis portofolio dan penilaian informal dalam proses pembelajaran.

Keempat, dalam pembelajaran whole language, anak-anak harus ditekankan pemaknaan kata atau bahasa agar karakter toleransi bisa tercapai. Anak tumbuh dan belajar lebih siap ketika mereka secara aktif mengajak dirinya sendiri untuk belajar. Dalam teknis di kelas, anak-anak diajak mencari masalah dan menyelesaikannya bersama-sama. Melalui kegiatan itu, mereka bisa hidup bergotong-royong sehingga mampu melahirkan karakter toleran.

Kelima, whole language didasarkan pada pengamatan banyak hal yang dipelajari pada diri siswa, sehingga guru perlu memberi kesempatan dan mendorong ke dalam proses belajar. Pembelajaran Bahasa Indoensia melalui whole language bisa merangsang peserta didik belajar mandiri. Guru memberikan bimbingan, membangun, mengembangkan jenis tingkah laku serta sikap dalam kemajuan belajar siswa. Dengan demikian, dalam menguatkan karakter toleran dalam pembelajaran Bahasa Indonesia akan mudah tercapai.

\section{Membangun Toleransi dari Sekolah}

Pembelajaran Bahasa Indonesia melalui pendekatan whole language diprioritaskan melahirkan karakter toleran, santun, peduli sosial dan pluralisme. Ada sejumlah indikator atau bentuk-bentuk toleransi beragama. Mulai tidak memaksa dalam beragama, menghormati keyakinan orang lain, tolong-menolong urusan muamalah dunia, tidak boleh mencaci sesembahan dan berbuat adil. ${ }^{69}$

Indikator karakter toleran ada dua dimensi. Pertama, kepada sesama manusia muslim, berupa sikap/perilaku tolong-menolong, saling menghargai, menyayangi, menasihati, dan tidak mencurigai. Kedua, toleran kepada manusia non-muslim, seperti menghargai kepada hak-hak mereka dan secara luas dalam kehidupan bermasyarakat dan bernegara. Prinsip toleransi itu bisa dilakukan dengan bertetangga dengan baik, saling membantu, membela yang teraniaya, saling menasihati, dan menghormati kebebasan beragama. ${ }^{70}$

Sebagai negara yang memiliki kekayaan budaya dan keragaman tinggi, Indonesia harus toleran dalam beragama. Agama di Indonesia memiliki warna tersendiri, sehingga menghiasi sisi kehidupan. Seluk-beluk pemikiran dan agama di Indonesia muncul melalui aspek kehidupan

69 Hendri Gunawan, “Toleransi Beragama Menurut Pandangan Hamka Dan Nurcholis Madjid," Skripsi, FAI UMS 2015, Hlm. 5.

70 Ahmad Sholeh, "Pemahaman Konsep Tasamuh (Toleransi) Siswa dalam Ajaran Islam”, Jurnal J-PAI, Vol. 1 No.1 Juli-Desember 2014, hlm. 106. 
lainnya, seperti seni, masakan, hubungan sosial, dan arsitektur. Perbedaan dalam beragama ini menjadi ciri khas bangsa Indonesia dan toleransi beragama urgen dalam mengembangan Bhineka Tunggal Ika.

Pengembangan karakter toleransi beragama dapat dilakukan melalui pendidikan karakter. Sekolah berperan mengembangkan pendidikan karakter toleransi beragama. Pendidikan karakter menjadi fondasi utama menumbuhkan karakter melalui pendidikan. Harapannya, internalisasi butir-butir refleksi dalam karakter toleransi beragama. Pertama, kedamaian antaragama. Kedua, terbuka dan reseptif pada indahnya perbedaan beragama. Ketiga, menghargai individu dan perbedaan yang berbeda agama. Keempat, saling menghargai agama satu dengan yang lain.

Kelima, benih dari intoleransi beragama adalah ketakutan dan ketidakpedulian. Keenam, benih dari toleransi beragama adalah cinta dan kasih sayang. Ketujuh, jika tidak cinta dan kasih sayang, tidak ada toleransi beragama. Kedelapan, yang tahu menghargai kebaikan dalam diri orang lain dan situasi memiliki toleransi beragama. Kesembilan, toleransi beragama berarti menghadapi situasi sulit bersama. Kesepuluh, toleransi beragama terhadap ketidaknyamanan hidup dengan membiarkan berlalu, ringan, dan membiarkan orang lain. ${ }^{71}$

Dari penjelasan di atas, dapat disimpulkan ke dalam beberapa hal. Pertama, toleransi beragama sangat strategis dikuatkan di sekolah melalui penguatan pendidikan karakter. Toleransi bisa dimulai dari hal-hal kecil dalam pembelajaran Bahasa Indonesia. Kedua, ada dua inti dari indikator karakter toleran. Mulai dari kepada sesama manusia muslim, berupa sikap/ perilaku tolong-menolong, saling menghargai, menyayangi, menasihati, dan tidak mencurigai, dan toleran kepada manusia non-muslim. Ketiga, internalisasi toleransi bisa dikuatkan dalam sepuluh tindakan yang pada intinya menghargai perbedaan, dan mengutamakan toleransi.

Toleransi harus dibangun, dikuatkan, dan digerakkan dari ruang kelas. Madrasah Ibtidaiyah sebagai lembaga pendidikan formal wajib bersumbangsih menguatkan karakter toleran melalui pembelajaran Bahasa Indonesia dengan pendekatan whole language. Pendekatan ini menekankan pemahaman bahasa utuh, menyeluruh yang sangat terkait bahasa, budaya, dan kultur manusia Indonesia. Sebagai alat pemersatu, Bahasa Indonesia menjadi alat pembentuk karakter toleran yang melekat di dalamnya.

\section{Simpulan}

Dari kajian di atas ada beberapa simpulan. Pertama, Penguatan Pendidikan Karakter (PPK) menjadi amanat undang-undang. Ada 17 karakter yang wajib dikuatkan di jenjang MI/SD. Mulai dari religius, jujur, toleran, disiplin, bekerja keras, kreatif mandiri, demokratis, rasa ingin tahu, semangat kebangsaan, cinta tanah air, menghargai prestasi, komunikatif, cinta damai, gemar membaca, peduli lingkungan, peduli sosial, dan bertanggungjawab. Toleran, menjadi salah satu karakter yang urgen dikuatkan di era Revolusi Industri 4.0 ini karena sudah banyak bahasa/kata-kata, pikiran, tindakan, dan gerakan intoleran.

71 Amien Wahyudi, "Character Education: Literatur Study Religious Tolerance Character", Prosiding Seminar Bimbingan dan Konseling, Vol. 1, No. 1, 2017, hlm.49. 
Kedua, bahasa yang digunakan anak-anak merepresentasikan karakternya. Semakin santun, halus, dan toleran bahasa yang mereka gunakan, semakin kuat karakter santun, halus, dan toleran pada anak, begitu pula sebaliknya. Ketiga, pembelajaran Bahasa Indonesia dengan pendekatan whole language bisa menguatkan karakter toleran karena dilakukan secara utuh, integral, tidak parsial dari aspek menyimak, membaca, menulis dan berbicara. Pemahamannya juga tidak sekadar tekstual, namun juga kontekstual bahkan intertekstual.

Keempat, pembelajaran Bahasa Indonesia melalui pendekatan whole language didedikasikan melahirkan karakter toleran, santun, peduli sosial dan bermuara pada sikap pluralisme. Indikator atau bentuk-bentuk toleransi beragama ada dua, kepada muslim, dan toleran kepada nonmuslim.

\section{Bibliografi}

Aeni, Ani Nur, "Pendidikan Karakter untuk Siswa SD dalam Perspektif Islam”, Jurnal Mimbar Sekolah, Volume 1 Nomor 1, April 2014.

Amany, Tsamara, "Ini Dia 6 Ormas Yang Harus Dibubarkan Pemerintah," Artikel, 17 Januari 2016,redaksiindonesia.com/read/ini-dia-6-ormas-yang-harus-dibubarkanpemerintah.html diakses pada 19 Juli 2018.

Arifin, Bustanul, “Implikasi Prinsip Tasamuh (Toleransi) Dalam Interaksi Antar Umat Beragama”, Jurnal Fikri, Vol. 1, No. 2, Desember 2016.

Aunillah, Nurla Isna, 2011, Panduan Menerapkan Pendidikan Karakter di Sekolah, Jogjakarta: Laksana.

Austin, John Langshaw, 1975, How to Do Things with Words, Second Edition, Cambridge, Mass: Harvard University Press.

Aziz, EA, “Gaya Ki Sunda Menyatakan 'Tidak’: Sebuah Telaah Sosiolinguistik Terhadap Variabel Sosial yang Mempengaruhi Realisasi Kesantunan dalam Pertuturan Menolak oleh Orang Sunda," Makalah Konferensi Internasional Budaya Sunda 1, UPI Bandung, 2001.

Brown, H.D, 1997, Principle of Language Learning and Teaching, London: Prentice Hall International Limited.

Chamidi, Agus Salim dan Murtopo, Bahrun Ali, "Manajemen Pendidikan Karakter Mabadi Khaira Ummah di SMK Maarif 2 Gombong," Jurnal Wahana Akademika, Volume 5 Nomor 1, April 2018.

Dahlan, MD, "Pengembangan Kepribadian Mahasiswa Melalui Mata Kuliah Pengembangan 
Kepribadian”, Makalah, 30 Juli 2001.

Departemen Pendidikan Nasional, 1989, Kamus Besar Bahasa Indonesia, Jakarta: Balai Pustaka. Effendy, Onong Uchjana, 1993, Ilmu, Teori \& Filsafat Komunikasi, Bandung : PT. Citra Aditya Bakti.

Farhan, Moh., "Meneladani Nilai-nilai Karakter Komunitas Mahasantri (Studi Pondok Pesantren Asshodiqiyah Semarang)," Jurnal Wahana Akademika, Volume 5 Nomor 1, April 2018.

Firmansyah, "Jumlah Kejadian Bullying dari Tahun ke Tahun," etd.repository.ugm.ac.id diakses pada 20 Juli 2018.

Froese, V.F. (Ed), 1990, Whole-language: Practice and Theory, Scarborough, ON: Prentice-Hall Canada, Inc.

Gunawan, Hendri, “Toleransi Beragama Menurut Pandangan Hamka dan Nurcholis Madjid," Skripsi, FAI UMS 2015.

Hariyanto, "Pendekatan Whole Language Sebagai Upaya Peningkatan Kemampuan Menulis Pengalaman dalam Pembelajaran Bahasa Indonesia," Tesis, Program Pascasarjana Fakultas Pendidikan Bahasa Indonesia Universitas Sebelas Maret Surakarta tahun 2009.

Haryana, Diena, dkk, Seri Pendidikan Orang Tua: Ayo, Bantu Anak Hindari Perundungan, Jakarta: Direktorat Pembinaan Pendidikan Keluarga Direktorat Jendral Pendidikan Anak Usia Dini dan Pendidikan Masyarakat Kementerian Pendidikan dan Kebudayaan.

Hasan, H.M. Nur, "Model Pembelajaran Berbasis Pondok Pesantren dalam Membentuk Karakter Siswa di Pondok Pesantren Raoudhotut Tholibin Rembang Jawa Tengah," Jurnal Wahana Akademika, Volume 3 Nomor 2, Oktober 2016.

Hidayah, Nurul, "Pendekatan Pembelajaran Bahasa Whole Language," Jurnal Terampil, Vol. 3, Nomor 3, Desember 2014.

Hornby, A.S, 1986, Oxford Advanced Learners Dictionary of Current English, London: Oxford University Press, Cet. ke-23.

Ibda, Hamidulloh, 2017, Media Pembelajaran Berbasis Wayang (Konsep dan Aplikasi), (Semarang: CV. Pilar Nusantara.

Ibda, Hamidulloh dan Wijayanti, Dian Marta, 2014, Siapkah Saya Menjadi Guru SD Revolusioner?, Depok: Kalam Nusantara.

Judiani, Sri, "Implementasi Pendidikan Karakter di Sekolah Dasar Melalui Penguatan Pelaksanaan Kurikulum," Jurnal Pendidikan dan Kebudayaan, Vol. 16, Edisi Khusus III, Oktober 2010. 
Kemendikbud, "Permendikbud Nomor 23 Tahun 2015 tentang Penumbuhan Budi Pekerti", simpuh.kemenag.go.id/regulasi/permendikbud_23_15.pdf diakses pada 20 Juli 2018. "Permendikbud Nomor 23 Tahun 2017 tentang Hari Sekolah" www. sahabatkeluarga.kemdikbud.go.id diakses pada 19 Juli 2018. , "Permendikbud Nomor 20 Tahun 2018 Tentang Penguatan Pendidikan Karakter Pada Satuan Pendidikan Formal," www.websiteedukasi.com diunduh pada 20 Juli 2018.

Lakoff, Robin, 1973, “The Logic of Politeness: Or, Minding Your P's And Q's”, in Corum, C. et al. (eds). Papers from the Ninth Regional Meeting of the Chicago Linguistic Society, Chicago: Chicago Linguistic Society.

Leech, Geoffrey Neil, 1983, Principles of Pragmatics, London: Longman.

Martianto, Dwi Astuti, 2002, Pendidikan Karakter: Paradigma Baru dalam Pembentukan Manusia, Yogyakarta: BPFE.

Matraji, Ubaid, “Mewaspadai Wabah Intoleransi di Sekolah”, Kolom, 5 Juli 2017, news.detik. com/kolom/d-3520475/mewaspadai-wabah-intoleransi-di-sekolah Diakses pada 18 Juli 2018 .

Megawangi, Ratna, 2007, Semua Berakar pada Karakter, Jakarta : Lembaga Penerbit Fakultas Ekonomi Universitas Indonesia.

Misrawi, Zuhairi, 2007, Al-Qur’an Kitab Toleransi, Jakarta : Pustaka Oasis.

Muhtarom, Ali, dkk, 2018, Islam Agama Cinta Damai (Upaya Menepis Radikalisme Beragama), Semarang: CV. Pilar Nusantara.

Munawwir, Ahmad Warson, Kamus al-Munawwir Arab Indonesia Terlengkap, (Surabaya: Pustaka Progresif, Edisi ke-2. Cet. ke-14.

Muthahhari, Terry, "Survei UIN Jakarta: Intoleransi Tumbuh di Banyak Sekolah dan Kampus”, Sosial Budaya, 8 November 2017, tirto.id/survei-uin-jakarta-intoleransi-tumbuh-dibanyak-sekolah-dan-kampus-czQL diakses pada 18 Juli 2018.

Prasetya, Eko, "7 Kampus Negeri Ternama Terpapar Radikalisme, UI dan Undip Termasuk", Berita, 31 Mei 2018, www.merdeka.com/peristiwa/7-kampus-negeri-ternamaterpapar-radikalisme-ui-dan-undip-termasuk.html diakses pada 19 Juli 2018.

Purwanto, Setyoadi, 2016, Pendidikan Karakter Melalui Seni, Yogyakarta: Pustaka Pelajar.

Redmond, Mary Lynn "The Whole Language Approach in the FLES Classroom: Adapting Strategies to Teach Reading and Writing", Article Foreighn Language Annals, American Council on the Teaching of Foreign Languages (ACTFL), October 1994.

Risnawati, V. Naniek, “Busana Mencerminkan Kepribadian,” Jurnal STIE Semarang, Vol 6, No 1, Edisi Februari 2014. 
Rochmi, Muhammad Nur, "Intoleransi Mulai Tumbuh dalam Pendidikan”, Berita, 3 Mei 2017, beritagar.id/artikel/berita/intoleransi-mulai-tumbuh-dalam-pendidikan diakses pada 18 Juli 2018.

Rofiqoh, Herlin Nur, "Model Pembelajaran Membaca Cerpen dengan Menggunakan Pendekatan Whole Languange pada Siswa Kelas Viii Smpn 1 Tarogong tahun Ajaran 2011/2012,” Makalah, Prodi Pendidikan Bahasa dan Sastra Indonesia STKIP Siliwangi Bandung tahun 2012.

Santosa, Puji, dkk, 2011, Materi dan Pembelajaran Bahasa Indonesia SD Cetakan ke-18, Jakarta: Universitas Terbuka.

Sauri, Sofyan, 2006, Pendidikan Berbahasa Santun, Bandung: PT. Genesindo.

Seken, I Ketut, "Penggunaan Peranti Pendukung untuk Melembutkan Ujaran: Sebuah Kasus Kesantunan Bahasa Bali”, Jurnal PRASI, Vol. 8 No. 15, Januari - Juni 2013.

Setkab, "Peraturan Presiden Republik Indonesia Nomor 87 Tahun 2017 tentang Penguatan Pendidikan Karakter (PPK)", setkab.go.id/wp-content/uploads/2017/09/Perpres Nomor 87 Tahun 2017.pdf diakses pada 20 Juli 2018.

Sholeh, Ahmad, "Pemahaman Konsep Tasamuh (Toleransi) Siswa dalam Ajaran Islam”, Jurnal J-PAI, Vol. 1 No.1 Juli-Desember 2014.

SM, Ismail, "Integrasi Pendidikan Karakter Anak Usia Dini Melalui Model Pembelajaran Berbasis Beyon Centers and Circle Time (BCCT)," Jurnal Wahana Akademika, Vol. 15. No.1. April 2013.

Solihin, Lianny, “Tindakan Kekerasan pada Anak dalam Keluarga”, Jurnal Pendidikan Penabur, No.03 / Th.III / Desember 2004.

Subana dan Sunarti, 2011, Strategi Belajar Mengajar Bahasa Indonesia, Cetakan III, Bandung: CV. Pustaka Setia.

Subyakto, Sri Utari dan Nababan, 1993, Metodologi Pengajaran Bahasa, Jakarta: Gramedia Pustaka Utama.

Sudipa, I Nengah, "Psycholinguistics : An Introductory Note," Essay Majalah, volume 16. English Department 2009, Udayana University.

Suharto, Toto, "Gagasan Pendidikan Muhamamdiyah dan NU sebagai Potret Pendidikan Islam Moderat di Indonesia,” Jurnal Islamica, Volume 9, Nomor 1, September 2014.

Suratinah dan Prakoso, Teguh, 2011, "Pendekatan Pembelajaran Bahasa dan Sastra Indonesia SD," dalam Materi dan Pembelajaran Bahasa Indonesia SD cetakan ke-18, Jakarta: Universitas Terbuka.

Susanti, Rini Dwi, "Pembelajaran Apresisasi Sastra di Sekolah Dasar”, Jurnal Elementary, Vol. 3 No. 1, Januari-Juni 2015. 
Sutjipto, "Pendidikan Budi Pekerti Pada Kurikulum Sekolah Dasar", Jurnal Pendidikan dan Kebudayaan, Vol. 20, Nomor 4, Desember 2014.

Teja, Mohammad, “Media Sosial: Ujaran Kebencian Dan Persekusi”, Majalah Info Singkat, Vol. IX, No. 11/I/Puslit/Juni/2017.

Tilaar, H.A.R, 2003, Pendidikan dan Kekuasaan: Suatu Tinjauan dari Perspektif Studi Kultural, Magelang: Indonesia Tera.

Tim Viva, "Kasus Bullying Anak Meningkat pada 2017”, www.viva.co.id/berita/nasional/938446kasus-bullying-anak-meningkat-pada-2017, 23 Juli 2017, diakses pada 20 Juli 2018.

Wahyudi, Amien, "Character Education: Literatur Study Religious Tolerance Character", Prosiding Seminar Bimbingan dan Konseling, Vol. 1, No. 1, 2017.

Walgito, Bimo, Pengantar Psikologi Umum, Yogyakarta: Fakultas Psikologi UGM. 